\title{
PENGARUH KUALITAS PRODUK, HARGA DAN CITRA MEREK TERHADAP KEPUTUSAN PEMBELIAN AIR MINUM DALAM KEMASAN MEREK AQUA DI KELURAHAN PABUARAN BOGOR
}

\author{
${ }^{1)}$ Wawan Hari Subagyo, ${ }^{2)}$ Ranti Chairunisha Febriana \\ ${ }^{1)}$ Dosen Program Studi Manajemen, STIE Dewantara \\ J1. Raya Pemda Bojong Depok Baru III, Karadenan, Cibinong, Bogor, Jawa Barat 16913, Indonesia \\ Email: wawan.hari@dewantara.ac.id \\ ${ }^{2)}$ Program Studi Manajemen, STIE Dewantara \\ J1. Raya Pemda Bojong Depok Baru III, Karadenan, Cibinong, Bogor, Jawa Barat 16913, Indonesia \\ Email: ranticf@gmail.com
}

\begin{abstract}
This research aims to determine the influence of variable product quality, price and brand image partial and simultaneous to the variable purchase decision of bottled drinking water of Aqua brand in the village of Pabuaran Bogor, as well as knowing the effect of independent variables on the dependent variable. The samples in this study were 97 people. Data analysis techniques use multiple linear regression. $T$ test result showed the product quality variable (X1) and brand image (X3) partially influential for the purchase decision of bottled drinking water (AMDK) Aqua brand in the village of Pabuaran Bogor. It is based on the calculated t count value of two variables greater than $t$ table and the Signification value ( $p$ value) is less than 0.1. Variable price (X2) partial has no significant effect on the variable purchase decision of bottled drinking water (AMDK) Aqua brand in the village of Pabuaran Bogor. F test results indicate product quality variables, prices, and brand image simultaneously affect the variable purchase decision of bottled drinking water (AMDK) Aqua brand in the village Pabuaran Bogor. This can be seen that the value F count 6.80 is greater than the $F$ table 2.70 and the significance (0.0) value is smaller than 0.1. The result of the coefficient of determination of $15.3 \%$ showed the influence of independent variables, such as product quality, price, brand image of the purchase decision variable. The remaining $84.7 \%$ is influenced by other variables not included in this study.
\end{abstract}

Keywords: Product Quality, Price, Brand Image, Purchase Decision, Pabuaran Village Bogor

\begin{abstract}
ABSTRAK
Penelitian ini bertujuan untuk mengetahui pengaruh variabel Kualitas Produk, Harga dan Citra Merek secara parsial dan simultan terhadap variabel Keputusan Pembelian air minum dalam kemasan merek Aqua di kelurahan Pabuaran Bogor, serta mengetahui besarnya pengaruh variabel bebas terhadap variabel terikat. Sampel dalam penelitian ini sebanyak 97 orang. Teknik analisis data menggunakan regresi linier berganda. Hasil uji t memperlihatkan variabel Kualitas Produk $\left(\mathrm{X}_{1}\right)$ dan Citra Merek $\left(\mathrm{X}_{3}\right)$ secara parsial berpengaruh signifikan terhadap Keputusan Pembelian air minum dalam kemasan (AMDK) merek Aqua di kelurahan Pabuaran Bogor. Hal ini berdasarkan nilai $\mathrm{t}_{\text {hitung }}$ dua variabel tersebut lebih besar dari $t$ table dan nilai signifikasi ( $\mathrm{p}$ value) kurang dari 0,1 . Variabel Harga $\left(\mathrm{X}_{2}\right)$ secara parsial tidak berpengaruh signifikan terhadap variabel Keputusan Pembelian air minum dalam kemasan (AMDK) merek Aqua di kelurahan Pabuaran Bogor. Hasil uji F menunjukkan variabel kualitas produk, harga, dan citra merek secara simultan berpengaruh terhadap variabel Keputusan Pembelian air minum dalam kemasan (AMDK) merek Aqua di kelurahan Pabuaran Bogor. Hal ini dapar dilihat nilai $F_{\text {hitung }} 6,80$ lebih besar dari $F_{\text {tabel }} 2,70$ dan nilai signifikansi $(0,0)$ lebih kecil dari 0,1 . Hasil uji koefisien determinasi sebesar $15,3 \%$ menunjukkan besarnya pengaruh variabel bebas yaitu Kualitas Produk, Harga, Citra Merek terhadap variable Keputusan Pembelian. Sisanya 84,7\% dipengaruhi oleh variabel lain yang tidak dimasukkan dalam penelitian ini.
\end{abstract}

Kata kunci: Kualitas Produk, Harga, Citra Merek, Keputusan Pembelian, Kelurahan Pabuaran Bogor. 


\section{PENDAHULUAN}

Air minum dalam kemasan (AMDK) merek Aqua merupakan air minum dalam kemasan pertama dan dikenal luas di Indonesia. Seiring perkembangan waktu, permintaan air minum dalam kemasan semakin meningkat sehingga bermunculan air minum dalam kemasan merek lain sebagai pesaing. Tabel 1 berikut menunjukkan pangsa pasar beberapa merek air minum dalam kemasan.

Tabel 1. Top Brand Index (TBI) Katagori Air Minum Dalam Kemasan (dalam Persen)

\begin{tabular}{|c|c|c|}
\hline Merk & $\mathbf{2 0 1 7}$ & $\mathbf{2 0 1 8}$ \\
\hline Aqua & $73.3 \%$ & $63.9 \%$ \\
\hline Ades & $4.1 \%$ & $7.6 \%$ \\
\hline Club & $4.5 \%$ & $3.4 \%$ \\
\hline 2 Tang & $1.8 \%$ & $3.2 \%$ \\
\hline Cleo & 0 & $2.7 \%$ \\
\hline Vit & $6.1 \%$ & 0 \\
\hline
\end{tabular}

Sumber : Top Brand Award

Seperti terlihat pada Tabel 1 tersebut di atas menunjukkan bahwa Aqua berada pada peringkat pertama jauh lebih besar dibandingkan merek Air Minum dalam Kemasan lainnya. Hal ini dapat dikatakan bahwa jumlah konsumen yang memilih merek Aqua lebih banyak. Data tersebut menunjukkan bahwa Aqua sebagai Market Leader air minum dalam kemasan di Indonesia mengungguli pesaing-pesaingnya. Akan tetapi, market share Aqua pada tahun 2018 sebesar $63.9 \%$ mengalami penurunan dari tahun sebelumnya 2017 yang sebesar $73.3 \%$. Hal ini disebabkan antara lain karena menjamurnya industri AMIU (Air Minum Isi Ulang) dengan harga jual 30\% dibawah harga AMDK. Untuk mengantisipasi hal tersebut, Aqua meningkatkan belanja iklan untuk memperkuat brand image produknya dibenak konsumen agar tetap mengkonsumsi produknya.

\subsection{Tujuan Penelitian}

Adapun tujuan penelitian ini adalah

1. Untuk mengetahui pengaruh Kualitas Produk, Harga dan Citra Merek secara parsial terhadap Keputusan Pembelian Air Minum Dalam Kemasan merek Aqua di kelurahan Pabuaran Bogor.

2. Untuk mengetahui pengaruh Kualitas Produk, Harga dan Citra Merek secara simultan terhadap Keputusan Pembelian Air Minum Dalam Kemasan merek Aqua di kelurahan Pabuaran Bogor.

3. Untuk mengetahui seberapa besar pengaruh Produk, Harga dan Citra Merek terhadap Keputusan Pembelian Air Minum Dalam Kemasan merek Aqua di kelurahan Pabuaran Bogor.

\section{TINJAUAN PUSTAKA}

\subsection{Landasan Teori}

\subsubsection{Kualitas Produk}

Menurut Kotler dan Armstrong (2012:283) Kualitas Produk adalah "the ability of a product to perform its functions, it includes the product's overall durability, reliability, precision, ease of operation and repair and other valued attributes" yang artinya kemampuan sebuah produk dalam memperagakan fungsinya, hal itu termasuk keseluruhan durabilitas, reliabilitas, ketepatan, kemudahan pengoperasian dan reparasi produk juga atribut produk lainnya.

Menurut Tjiptono (2008) mengemukakan, bahwa kualitas produk memiliki beberapa dimensi antara lain :

1. Kinerja (Performance) merupakan karakteristik operasi dan produk inti (core product) yang dibeli. Misalnya kecepatan, kemudahan dan kenyamanan dalam penggunaan

2. Fitur (Features)merupakan Ciri-ciri atau keistimewaan tambahan yaitukarakteristik sekunder atau pelengkap

3. Kesesuaian dengan spesifikasi (Conformance to Spesification) merupakan sejauh mana karakteristik desain dan operasi memenuhi standar 
yang telah ditetapkan sebelumnya. Misalnya pengawasan kualitas dan desain, standar karakteristik operasional

4. Keandalan (Realibility) merupakan kemungkinan kecil akan mengalami kerusakan atau gagal pakai. Misalnya pengawasan kualitas dan desain, standar karakteristik operasional

5. Daya tahan (Durability) berkaitan dengan berapa lama produk tersebut dapat terus digunakan. Dimensi ini mencakup umur teknis maupun umur ekonomis

6. Estetika (Esthetica) merupakan daya tarik produk terhadap panca indera. Misal keindahan desain produk, keunikan model produk, dan kombinasi

7. Kualitas yang dipersepsikan (Perceived Quality) merupakan persepsi konsumen terhadap keseluruhan kualitas atau keunggulan suatu produk. Biasanya karena kurangnya pengetahuan pembeli akan atributatau ciri-ciri produk yang akan dibeli, maka pembeli mempersepsikan kualitasnya dari aspek harga, nama merek, iklan, reputasi perusahaan, maupun negara pembuatnya.

8. Dimensi kemudahan perbaikan (Serviceability) meliputi kecepatan, kemudahan, penanganan keluhan yang memuaskan. Pelayanan yang diberikan tidak terbatas hanya sebelum penjualan, tetapi juga selamaproses penjualan hingga purna jual yang mencakup pelayanan reparasi dan ketersediaan komponen yang dibutuhkan.

\subsubsection{Harga}

Harga merupakan faktor utama dalam penentuan posisi dan harus diputuskan sesuai dengan pasar sasaran, bauran ragam produk, dan pelayanan, serta persaingan (Kotler dan Amstrong,2008).

Menurut Kotler dan Amstrong (2008), ada empat indikator yang mencirikan harga yaitu :

1. Keterjangkauan Harga. Harga yang diberikan oleh perusahaan terhadap produk mereka dapat dijangkau oleh para konsumennya. Harga yang sesuai dan terjangkau tentunya akan menjadi pertimbangan konsumen untuk membeli produk mereka.

2. Kesesuaian Harga dengan Kualitas Produk. Harga yang diberikan oleh perusahan terhadap produknya sesuai dengan kualitas produk yang mereka hasilkan, misalnya jika harganya tinggi maka kualitas produk yang diberikan pun memiliki kualitas yang tinggi sehingga konsumen pun merasa tidak keberatan jika membeli produk tersebut.

3. Daya Saing Harga. Dalam pasar, perusahaan sebaiknya juga memperhatikan bahwa harga yang diberikan memiiki daya saing yang tinggi terhadap para kompetitornya. Jika harga yang diberikan terlampau tinggi di atas harga para kompetitor maka produk tersebut tidak memiliki daya saing yang baik.

4. Kesesuaian Harga dengan Manfaat. Manfaat produk yang dimiliki harus sesuai dengan harga yang diberikan oleh perusahaan terhadap produk mereka. Ada baiknya jika harga yang tinggi memiliki manfaat produk yang tinggi pula.

\subsubsection{Citra Merek}

Citra merek adalah seperangkat keyakinan ide dan kesan yang terbentuk oleh seseorang terhadap suatu obyek image atau citra tersendiri suatu gambaran, penyerupaan kesan utama, oleh karena itu citra atau merek dapat dipertahankan agar produk atau jasa menghasilkan image atau merek yang baik (Kotler, 2009).

Menurut pendapat Kotler dan Keller (2013) pengukur citra merek adalah subjektif, yang artinya tidak ada ketentuan buku untuk mengukur citra merek (brand image). Pengukur citra merek dapat dilakukan berdasarkan aspek sebuah merek dalam kaitannya dengan asosiasi merek, yaitu: 
1. Kekuatan Asosiasi Merek (Strength of Brand Association). Kekuatan asosiasi merek tergantung pada bagaimana informasi masuk dalam ingatan konsumen dan bagaimana informasi dikelola data sensor di otak konsumen. Setiap konsumen mengikuti, mengatur dan menginterpretasikan data sensoris menurut cara masing-masing. Persepsi konsumen tidak tergantung stimulasi fisik, tetapi lingkungan dan keadaan individunya. Perbedaan pandang pelanggan terhadap merek akan menciptakan persepsi dalam perilaku pembelian yang berbeda.

2. Keunikan Asosiasi Merek (Uniqueness of Brand Association). Asosiasi yang kuat dan unik sangat penting bagi keberhasilan sebuah merek. Asosiasi merek membantu ruang lingkup persaingan dengan produk dan layanan lain (Keller, 2008). Membuat kesan unik menunjukkan perbedaan yang signifikan diantara merek-merek lain sebagai nilai saing dan membuat konsumen tertarik untuk memilih merek tersebut. Tujuannya menciptakan asosiasi yang kuat dan unik yang melekat dalam benak konsumen dan mendalam.

3. Keunggulan Asosiasi Merek (Favorability of Brand Association). Keunggulan asosiasi merek dapat membuat konsumen percaya bahwa atribut dan manfaat merek dapat memuaskan kebutuhan dan keinginan konsumen, sehingga menciptakan sikap positif terhadap merek tersebut. Tujuan konsumsi oleh konsumen adalah memperoleh kepuasan. Kepuasan akan tercapai jika kinerja produk dan merek melebihi harapan konsumen.

\subsubsection{Keputusan Pembelian}

Keputusan pembelian menurut Swastha dan Handoko (2008 : 110) keputusan pembelian merupakan proses dalam pembelian yang nyataapakah membeli atau tidak dari berbagai yang mempengaruhi konsumen dalam melakukan pembelian suatu produk atau jasa, biasanya konsumen selalu mempertimbangkan kualitas merek, harga, produk setelah itu konsumen dapat melakukan evaluasi pilihan dan dapat menentukan sikap yang akan diambil.

Indikator-indikator keputusan pembelian, menurut Kotler (2007), yaitu :

1. Kemantapan pada sebuah produk. Kualitas produk yang sangat baik akan membangun kepercayaan konsumen sehingga menunjang kepuasan konsumen.

2. Kebiasaan dalam membeli produk. Kebiasaan merupakan pengulangan sesuatu secara terus-menerus dalam melakukan pembelian produk yang sama.

3. Memberikan rekomendasi kepada orang lain. Merekomendasikan diartikan sebagai menyarankan, mengajak untuk berbuat sesuatu atau menganjurkan suatu bentuk perintah membeli suatu produk yang dipercaya.

4. Melakukan pembelian ulang. Individu yang melakukan pembelian produk atau jasa dan menentukan untuk membeli lagi, maka pembelian kedua dan selanjutnya disebut pembelian ulang.

\subsection{Kerangka Pemikiran}

Menurut Sekaran dalam Sugiyono (2011) kerangka berpikir merupakan model konseptual tentang bagaimana teori berhubungan dengan berbagai faktor yang telah didefinisikan sebagai hal yang penting. Kerangka pemikiran penelitian ini dapat dilihat pada Gambar 1 berikut. 


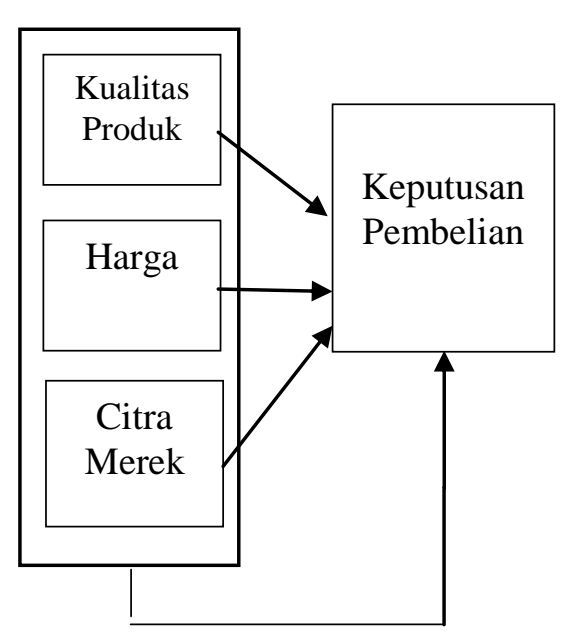

\section{Gambar 1. Kerangka Pemikiran Penelitian}

Berdasarkan konsep pemikiran diatas maka dalam penelitian ini hipotesis yang diajukan adalah sebagai berikut:

1. $\mathrm{H}_{0}$ : Tidak terdapat pengaruh Produk $\left(\mathrm{X}_{1}\right)$, Harga $\left(\mathrm{X}_{2}\right)$ dan Citra Merek $\left(\mathrm{X}_{3}\right)$ secara parsial terhadap Keputusan Pembelian air minum dalam kemasan merek Aqua di kelurahan Pabuaran Bogor.

$\mathrm{H}_{1}$ : Terdapat pengaruh Produk $\left(\mathrm{X}_{1}\right)$, Harga $\left(\mathrm{X}_{2}\right)$ dan Citra Merek $\left(\mathrm{X}_{3}\right)$ secara parsial terhadap Keputusan Pembelian air minum dalam kemasan merek Aqua di kelurahan Pabuaran Bogor.

2. $\mathrm{H}_{0}$ : Tidak terdapat pengaruh Produk $\left(\mathrm{X}_{1}\right)$, Harga $\left(\mathrm{X}_{2}\right)$ dan Citra Merek $\left(X_{3}\right)$ secara simultan terhadap Keputusan Pembelian air minum dalam kemasan merek Aqua di kelurahan Pabuaran Bogor.

$\mathrm{H}_{2}$ : Terdapat pengaruh Produk $\left(\mathrm{X}_{1}\right)$, Harga $\left(\mathrm{X}_{2}\right)$ dan Citra Merek $\left(\mathrm{X}_{3}\right)$ secara simultan terhadap Keputusan Pembelian air minum dalam kemasan merek Aqua di kelurahan Pabuaran Bogor.

\section{METODE PENELITIAN}

\subsection{Jenis Penelitian}

Pendekatan pada penelitian ini adalah penelitian kuantitatif, yaitu penelitian yang menggunakan data berupa angka yang dianalisis menggunakan analisis statistik. Jenis penelitian adalah kausalitas merupakan penelitian yang meneliti hubungan sebab akibat antara dua variable atau lebih.

\subsection{Populasi dan Sampel}

Populasi merupakan wilayah generalisasi yang terdiri atas objek atau subjek yang mempunya kualitan dan karakteristik tertentu yang ditetapkan oleh peneliti untuk dipelajari dan kemudian ditarik kesimpulannya (Sugiyono, 2011). Populasi dalam penelitian ini adalah konsumen yang mengkonsumsi produk air minum dalam kemasan merek Aqua di Kelurahan Pabuaran Bogor.

Teknik pengambilan sampel dengan menggunakan teknik purposive sampling yaitu teknik penentuan sample dengan melihat pertimbangan kriteria tertentu. Adapun kriteria yang ditetapkan oleh penulis sebagai responden adalah sebagai berikut :

a. Responden berusia 17 hingga 50 tahun, karena pada usiatersebut merupakan usia produktif dan dianggap sebagai usia yang matang untuk dapat memilih keputusan.

b. Responden merupakan konsumen yang mengkonsumsi produk Aqua.

Adapun penetapan ukuran sampel dalam penelitian ini menggunakan rumus menurut Rao Purba (Sujarweni, 2015:155), yaitu :

$$
\mathrm{N}=\frac{Z^{2}}{4(M \circ e)^{z}}
$$

\section{Keterangan:}

$\mathrm{N}$ = Jumlah sampel

$\mathrm{Z}$ = Tingkat distribusi normal pada taraf signifikan $(95 \%=1,96)$

Moe $=$ Margin of error kesalahan maksimum yang bisa ditolerir sebesar 10\% dengan rumus di atas, maka diperoleh perhitungan :

$$
\begin{aligned}
& \mathrm{N}=\frac{1,96^{2}}{4(0.1)^{2}} \\
& =96,04
\end{aligned}
$$


Berdasarkan perhitungan di atas, maka jumlah responden yang akan dijadikan sampel penelitian adalah sebanyak 96,04 orang, yang dibulatkan menjadi 97 orang.

\subsection{Variabel Penelitian}

Variabel penelitian adalah sesuatu yang berbentuk apasaja yang ditetapkan oleh seorang peneliti untuk dipelajari sehingga diperoleh informasi mengenai hal tersebut, kemudian ditarik kesimpulannya, Sugiyono (2009:). Pada penelitian ini menggunakan 4 variabel yaitu 3 variabel bebas (independen) yaitu Kualitas Produk $\left(\mathrm{X}_{1}\right)$, Harga $\left(\mathrm{X}_{2}\right)$ dan Citra Merek $\left(\mathrm{X}_{3}\right)$. Serta 1 variabel Keputusan Pembelian (Y) merupakan variabel terikat (dependen).

\subsection{Teknik Pengumpulan Data}

Pengumpulan data pada penelitian ini menggunakan data primer melalui kuesioner dengan skala Likert menggunakan 5 kategori pengukuran. Jumlah pertanyaan sebanyak 29 buah. Selain itu, menggunakan data sekunder, sumber data penelitian yang diperoleh secara tidak langsung melalui media perantara atau data yang diperoleh dari pihak lain. Data sekunder meliputi studi pustaka, yaitu pengumpulan data yang diperoleh dari dokumen dan literatur.

\subsection{Analisis Data}

\subsubsection{Metode Uji Kuesioner}

Metode uji kuesioner yang digunakan pada penelitian ini yaitu uji validitas dan reliabilitas.

\section{Uji Validitas}

Uji validitas untuk menguji validitas konstuk yang dilakukan dengan cara mengkorelasikan antara skor butir pertanyaan dengan skor totalnya (Sugiyono, 2010). Kriteria pengujian validitas dengan taraf signifikan $(\alpha)$ adalah $10 \%$ dan $\mathrm{df}=\mathrm{N}$ 2, apabila $r_{\text {-hitung }}>r_{\text {-tabel }}$, maka ada korelasi yang nyata antara kedua variabel tersebut sehingga kuesioner sebagai alat pengukur dikatakan valid. Demikian juga sebaliknya apabila nilai $r_{\text {-hitung }}<r_{\text {-tabel }}$ maka tidak ada korelasi yang nyata antara kedua variabel tersebut sehingga kuesioner sebagai alat pengukur dikatakan tidak valid.

\section{Uji Reliabilitas}

Reliabilitas memiliki berbagai nama lain seperti kepercayaan, kehandalan dan kestabilan. Tujuan pengujian reliabilitas adalah untuk melihat apakah instrumen penelitian merupakan instrumen yang handal dan dapat dipercaya. Ide pokok dalam konsep reliabilitas adalah sejauh mana hasil suatu pengukur dapat dipercaya (Juliandi, 2013).

Adapun kriteria dari pengujian reliabilitas adalah :

a. Jika nilai koefisien reliabilitas > 0,6 , maka instrumen yang diuji memiliki reliabilitas yang baik/ reliabel/ terpercaya.

b. Jika nilai koefisien relibilitas $<0,6$, maka instrumen yang diuji tersebut tidak reliabel.

\subsubsection{Metode Uji Data Asusmsi Klasik}

Pada penelitian ini metode uji data menggunakan uji normalitas, multikolinieritas dan heteroskedastisitas.

\section{Uji Normalitas}

Uji normalitas bertujuan untuk mengetahui apakah dalam model regresi,variabel terikat dan variabel bebas memiliki distribusi yang normal atau tidak, karena model regresi yang baik memiliki distribusi data yang normal atau mendekati normal. Uji normalitas menggunakan uji Kolmogorov Smirnov.

Kriteria dari pengujian Kolmogorov Smirnov adalah :

1. Jika nilai signifikan < 0,1 , maka distribusi data tidak normal.

2. Jika nilai signifikan > $>, 1$, maka distribusi data normal. 
2. Uji Multikolinieritas

Multikolinearitas

merupakan

hubungan linier yang sempurna antara beberapa atau semua variabel bebas. Pengujian multikolinearitas bertujuan untuk mengetahui apakah dalam model regresi ditemukan adanya korelasi antar variabel bebas. Dalam model regresi yang baik seharusnya tidak terjadi korelasi diantara variabel bebas. Multikolinearitas dapat dideteksi dengan menganalisis matrik korelasi variabel-variabel independen atau dengan menggunakan perhitungan nilai Tolerance dan VIF. Jika antar variabel independen ada korelasi yang cukup tinggi (lebih dari 0,900 ) maka hal ini menunjukkan adanya multikolinearitas atau jika nilai Tolerance kurang dari 0,1 atau nilai VIF lebih dari 10, maka hal ini menunjukkan adanya multikolinearitas (Ghozali, 2005).

\section{Uji Heteroskedastisitas}

Uji heteroskedastisitas digunakan untuk mengetahui perbedaan varians error setiap variabel $X$. Analisis regresi yang baik mensyaratkan tidak terjadi terjadi heteroskedastisitas atau terjadi homokedastisitas. Dalam penelitian ini peneliti menggunakan uji glejser dengan bantuan program SPSS. Uji glejser merupakan cara meregresi nilai kuadrat error atas seluruh variabel bebas, jika hasil pengujian nilai signifikansi $\mathrm{t} \leq 0,1$ maka menunjukkan terjadinya heteroskedastisitas. Sedangkan jika nilai signifikansi $\mathrm{t} \geq 0,1$ maka tidak terjadi heteroskedastisitas.

\subsubsection{Analisis Regresi Linier Berganda}

Teknik analisis data menggunakan regresi linier berganda, dengan persamaan regresi sebagai berikut :

$$
\mathrm{Y}=\mathrm{a}+\mathrm{b}_{1} \mathrm{X}_{1}+\mathrm{b}_{2} \mathrm{X}_{2}+\mathrm{b}_{3} \mathrm{X}_{3}
$$

Keterangan :

Y : Keputusan Pembelian

a : Konstanta b : Koefisien

$\mathrm{X}_{1}$ : Kualitas Produk

$\mathrm{X}_{2}$ : Harga

$\mathrm{X}_{3}$ : Citra Merek

\subsection{Metode Uji Hipotesis}

Pada penelitian ini metode uji hipotesis menggunakan uji secara parsial (uji t), uji secara simultan (uji F) dan dan uji koefisien determinasi.

\section{Uji Signifikansi Parsial (Uji t)}

Uji $t$ digunakan untuk menguji signifikansi hubungan antara variabel $\mathrm{X}$ dan $\mathrm{Y}$, apakah variabel $\mathrm{X}_{1}, \mathrm{X}_{2}, \mathrm{X}_{3}$ (Kualitas Produk, Harga, Citra Merek) benar-benar berpengaruh terhadap variabel Y (Keputusan Pembelian) secara terpisah atau parsial (Ghozali, 2005).

Kriteria Pengujian :

1. $\mathrm{H}_{0}$ diterima dan $\mathrm{H}_{1}$ ditolak, jika nilai $\mathrm{t}$ hitung $<\mathrm{t}$ tabel atau jika nilai signifikan > 0,1 . Artinya variabel independen tidak berpengaruh signifikan terhadap variable dependen.

2. $\mathrm{H}_{0}$ ditolak dan $\mathrm{H}_{1}$ diterima, jika nilai $\mathrm{t}$ hitung $>\mathrm{t}_{\text {tabel }}$ atau jika nilai signifikan $<$ 0,1 . Artinya variabel independen berpengaruh signifikan terhadap variable dependen.

\section{Uji Signifikansi Simultan (Uji F)}

Uji $F$ digunakan untuk mengetahui apakah semua variabel bebassecara bersamasama dapat berpengaruh terhadap variabel terikat. Pengujian ini dilakukan dengan membandingkan nilai $\mathrm{F}$ hitung dengan nilai $\mathrm{F}$ tabel. Uji $\mathrm{F}$ pada prinsipnya bertujuan untuk mengetahui pengaruh dari dua variable independent atau lebih secara simultan terhadap variable dependent (Sugiyono, 2015). Kriteria Pengujian :

1. Jika nilai $\mathrm{F}$ hitung $>\mathrm{F}$ tabel dan nilai signifikan $<0,1$ maka variable bebas secara simultan berpengaruh terhadap variable terikat. 
2. Jika nilai $\mathrm{F}$ hitung $<\mathrm{F}$ tabel dan nilai signifikan > 0,1 maka variable bebas secara simultan tidak berpengaruh terhadap variable terikat.

\subsection{Uji Koefisien Determinasi $\left(\mathbf{R}^{2}\right)$}

Koefisien determinasi $\left(R^{2}\right)$ artinya mengukur seberapa jauh kemampuan model dalam menerangkan variasi variabel terikat. Nilai $R^{2}$ yang kecil berarti kemampuan variabel bebas dalam menjelaskan variabel terikat sangat terbatas. Nilai R2 yang mendekati 1 berarti kemampuan variabel bebas memberikan semua informasi yang dibutuhkan untuk memprediksi variasi variabel terikat secara simultan.

\section{HASIL DAN PEMBAHASAN}

\subsection{Uji Validitas}

Uji validitas dilakukan untuk menguji apakah kuisioner layak untuk digunakan sebagai instrumen penelitian atau tidak. Pada penelitian ini diterapkan dengan jumlah sampel sebanyak 97 orang, jumlah konstruk = 2. Maka didapat nilai df-nya $=97-2=95$. Pada tabel $r$, nilai koefisien korelasi $r$ dengan nilai $\mathrm{df}=95$, maka diperoleh nilai $\mathrm{r}=0,168$. Dengan menggunakan bantuan program SPSS (Statisticfor Productsand Service Solution), berdasarkan hasil pengujian uji validitas diperoleh hasil nilai variabel Kualitas Produk, Harga, Citra Merek dan Keputusan Pembelian semua item pertanyaan kuesioner dinyatakan valid karena nilai $r_{\text {hitung }}$ lebih besar dari $r_{\text {tabel }}$.

Tabel 2. Uji Validitas Variabel Kualitas Produk

\begin{tabular}{|c|c|c|c|c|}
\hline No & $\begin{array}{c}\text { Item } \\
\text { Pernyataan }\end{array}$ & r hitung & r tabel & Keterangan \\
\hline 1 & P1 & 0,662 & 0,1680 & Valid \\
\hline 2 & P2 & 0,454 & 0,1680 & Valid \\
\hline 3 & P3 & 0,499 & 0,1680 & Valid \\
\hline 4 & P4 & 0,520 & 0,1680 & Valid \\
\hline 5 & P5 & 0,621 & 0,1680 & Valid \\
\hline 6 & P6 & 0,651 & 0,1680 & Valid \\
\hline 7 & P7 & 0,544 & 0,1680 & Valid \\
\hline
\end{tabular}

Sumber : Hasil Penelitian,2018 (data diolah)

Dari tabel 2, berdasarkan uji validitas diperoleh hasil 7 item pernyataan pada variabel Kualitas Produk $\left(\mathrm{X}_{1}\right)$ adalah valid karena karena nilai $r_{\text {hitung }}$ lebih besar dari $r$ tabel.

Tabel 3. Uji Validitas Variabel Harga

\begin{tabular}{|c|c|c|c|c|}
\hline No & $\begin{array}{c}\text { Item } \\
\text { Pernyataan }\end{array}$ & r hitung & r tabel & Keterangan \\
\hline 1 & P1 & 0,782 & 0,1680 & Valid \\
\hline 2 & P2 & 0,755 & 0,1680 & Valid \\
\hline 3 & P3 & 0,754 & 0,1680 & Valid \\
\hline 4 & P4 & 0,678 & 0,1680 & Valid \\
\hline
\end{tabular}

Sumber : Hasil Penelitian,2018 (data diolah)

Dari tabel 3. berdasarkan uji validitas diperoleh hasil 4 item pernyataan pada variabel Harga $\left(\mathrm{X}_{2}\right)$ adalah valid karena karena nilai $\mathrm{r}_{\text {hitung }}$ lebih besar dari $\mathrm{r}_{\text {tabel}}$.

\section{Tabel 4. Uji Validitas Variabel Citra} Merek

\begin{tabular}{|c|c|c|c|c|}
\hline No & $\begin{array}{c}\text { Item } \\
\text { Pernyataan }\end{array}$ & r hitung & r tabel & Keterangan \\
\hline 1 & P1 & 0,484 & 0,1680 & Valid \\
\hline 2 & P2 & 0,699 & 0,1680 & Valid \\
\hline 3 & P3 & 0,631 & 0,1680 & Valid \\
\hline 4 & P4 & 0,672 & 0,1680 & Valid \\
\hline 5 & P5 & 0,673 & 0,1680 & Valid \\
\hline 6 & P6 & 0,502 & 0,1680 & Valid \\
\hline 7 & P7 & 0,685 & 0,1680 & Valid \\
\hline 8 & P8 & 0,565 & 0,1680 & Valid \\
\hline
\end{tabular}

Sumber : Hasil Penelitian,2018 (data diolah)

Dari tabel 4. berdasarkan uji validitas diperoleh hasil 4 item pernyataan pada variabel Citra Merek $\left(\mathrm{X}_{3}\right)$ adalah valid karena karena nilai $r_{\text {hitung }}$ lebih besar dari $r_{\text {tabel. }}$.

Tabel 5. Uji Validitas Variabel Keputusan Pembelian

\begin{tabular}{|c|c|c|c|c|}
\hline No & $\begin{array}{l}\text { Item } \\
\text { Pernyataan }\end{array}$ & $\mathrm{r}$ hitung & $\mathrm{r}$ tabel & Keterangan \\
\hline 1 & P1 & 0,624 & 0,1680 & Valid \\
\hline 2 & P2 & 0,585 & 0,1680 & Valid \\
\hline 3 & P3 & 0,640 & 0,1680 & Valid \\
\hline 4 & P4 & 0,487 & 0,1680 & Valid \\
\hline 5 & P5 & 0,599 & 0,1680 & Valid \\
\hline 6 & P6 & 0,492 & 0,1680 & Valid \\
\hline 7 & P7 & 0,635 & 0,1680 & Valid \\
\hline 8 & P8 & 0,620 & 0,1680 & Valid \\
\hline 9 & P9 & 0,570 & 0,1680 & Valid \\
\hline 10 & P10 & 0,383 & 0,1680 & Valid \\
\hline
\end{tabular}

Sumber : Hasil Penelitian,2018 (data diolah)

Dari tabel 5. berdasarkan uji validitas diperoleh hasil 4 item pernyataan pada variabel Keputusan Pembelian (Y) adalah 
valid karena karena nilai $\mathrm{r}_{\text {hitung }}$ lebih besar dari $r_{\text {tabel. }}$.

\subsection{Uji Reliabilitas}

Pengujian reliabilitas dalam penelitian ini dilakukan dengan menghitung besarnya nilai Croncbach's Alpha Instrumen dari masingmasing empat dimensi yang diuji. Berdasarkan hasil pengujian uji reliabilitas diperoleh hasil variable Kualitas Produk $(0,647)$, Harga $(0,728)$, Citra Merek $(0,766)$ dan Keputusan Pembelian $(0,762)$ semua instrumen dalam penelitian ini dapat dinyatakan reliabel/handal karena nilai Cronbach's Coefficient Alpha lebih besar dari 0,6 .

\subsection{Uji Normalitas}

Dalam penelitian ini uji normalitas dilakukan dengan metode Uji Kolmogrov Smirnov dengan bantuan software SPSS. Dengan adanya tes normalitas maka hasil penelitian bisa digeneralisasikan pada populasi. Dalam pandangan statistik itu sifat dan karakteristik populasi adalah terdistribusi secara normal. Dengan kriteria jika Asymp. Sig $>0,1$ maka data berdistribusi normal, jika Asymp. Sig $<0,1$ maka distribusi data tidak normal.

Tabel 6. Normalitas Kolmogorof Smirnov

\begin{tabular}{|ll|r|}
\hline & & $\begin{array}{r}\text { Unstandardized } \\
\text { Residual }\end{array}$ \\
\hline $\mathrm{N}$ & & 97 \\
Normal & Mean & .0000000 \\
Parameter & Std. Deviation & 3.46210358 \\
$\mathrm{~s}$, b & & \\
Most & Absolute & .070 \\
Extreme & Positive & .070 \\
Differenc & Negative & -.070 \\
es & & .070 \\
Test Statistic & $.200^{\mathrm{c}, \mathrm{d}}$ \\
Asymp. Sig. (2-tailed) & \\
\hline
\end{tabular}

Sumber : Hasil Penelitian,2018 (data diolah)

Berdasarkan tabel di atas, maka dapat dilihat bahwa nilai dari Asymp. Sig. (2 tailed) adalah 0,200 di atas 0,1. Berdasarkan hasil tersebut maka dapat dinyatakan bahwa data penelitian ini terdistribusi normal.

\subsection{Uji Multikolinieritas}

Pengujian ini dilakukan untuk melihat apakah pada model regresi ditemukan adanya korelasi antar variabel independen. Jika terjadi korelasi yang kuat, maka dapat dikatakan telah terjadi masalah multikolinearitas dalam model regresi.

Tabel 7. Uji Multikolinearitas

\begin{tabular}{|l|c|c|}
\hline \multicolumn{1}{|c|}{ Variabel } & Toleransi & VIF \\
\hline Kualitas Produk & 0,826 & 1,211 \\
\hline Harga & 0,757 & 1,322 \\
\hline Citra Merek & 0,846 & 1,183 \\
\hline
\end{tabular}

Sumber : Hasil Penelitian, 2018 (data diolah)

Berdasarkan data di atas, maka dapat disimpulkan bahwa tidak ada nilai tolerance dari variabel Kualitas Produk, Harga dan Citra Merek lebih dari 0,1 dan nilai VIF kurang dari 10. Berdasarkan hasil tersebut maka dapat dinyatakan bahwa tidak terjadi multikolinearitas pada data penelitian.

\subsection{Uji Heteroskedastisitas}

Pada uji Glejser, nilai residual absolut diregresikan dengan variabel independen. Jika variabel independen signifikan secara statistik mempengaruhi variabel dependen, maka terdapat indikasi terjadi heteroskedastisitas. Jika Sig > 0,1 maka tidak terjadi heterokedastisitas, sebaliknya jika Sig $<0,1$ maka terjadi heterokedastisitas.

Tabel 8. Uji Heteroskedastisitas Uji Glejser

\begin{tabular}{|l|c|c|}
\hline Variabel & $\mathrm{t}$ & \multicolumn{1}{|c|}{ Sig } \\
\hline Constant & .499 & .619 \\
\hline Kualitas Produk & .020 & .984 \\
\hline Harga & 1.326 & .188 \\
\hline Citra Merek & -.858 & .393 \\
\hline
\end{tabular}

Sumber : Hasil Penelitian,2018 (data diolah)

Berdasarkan table di atas, nilai sig semua variabel tersebut $>0,1$. Maka dapat disimpulkan bahwa tidak terjadi heteroskedastisitas. Dengan demikian syarat analisis asumsi klasik dalam penelitian ini terpenuhi. 


\subsection{Uji Analisis Regresi Linier Berganda}

Analisis regresi linier berganda digunakan untuk mengetahui adanya pengaruh Kualitas Produk, Harga, Citra Merek terhadap Keputusan Pembelian air minum dalam kemasan merek Aqua di kelurahan pabuaran Bogor. Hasil uji t dapat dilihat pada tabel berikut.

\section{Tabel 9. Hasil Uji t (Uji Parsial)}

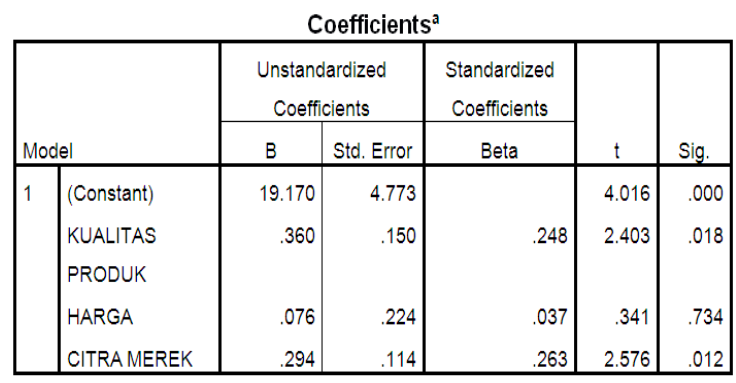

a. Dependent Variable: KEPUTUSAN PEMBELIAN

Sumber : Hasil Penelitian, 2018 (data diolah)

Berdasarkan Tabel 9, diperoleh hasil persamaan regresi sebagai berikut :

\section{$Y=19,170+0,360 X_{1}+0,076 X_{2}+0,294 X_{3}$}

Berdasarkan persamaan regresi tersebut dapat dijelaskan sebagai berikut :

1. Nilai konstanta 19,170 (nilai positif) pada persamaan regresi di atas mempunyai arti bahwa jika tidak ada perubahan nilai variable Kualitas Produk, Harga, Citra Merek maka nilai Keputusan Pembelian akan konstan sebesar 19,170.

2. Nilai 0,360 (nilai positif), mempunyai arti jika nilai variabel Kualitas Produk $\left(\mathrm{X}_{1}\right)$ meningkat sebesar 1 satuan, dengan asumsi variable bebas lainnya tetap, maka akan menaikkan nilai variabel Keputusan Pembelian (Y) sebesar 0,360.

3. Nilai 0,076 (nilai positif), mempunyai arti jika variabel Harga $\left(\mathrm{X}_{2}\right)$ meningkat sebesar 1 satuan, dengan asumsi variabel bebas lainnya tetap, maka akan menaikkan nilai variabel Keputusan Pembelian (Y) sebesar 0,076.

4. Nilai 0,294 (nilai positif), mempunyai arti jika variabel Citra Merek $\left(\mathrm{X}_{3}\right)$ meningkat sebesar 1 poin, dengan asumsi variabel bebas lainnya tetap, maka akan menaikkan nilai Keputusan Pembelian (Y) sebesar 0,294 .

\subsection{Uji t (Uji Parsial)}

Untuk mengetahui pengaruh variabel independen terhadap variabel dependen secara parsial, instrumen yang digunakan adalah statistik uji t. Dengan df $=\mathrm{n}-\mathrm{k}=97-4=93$ dan nilai kesalahan $10 \%$, maka nilai $\mathrm{t}_{\text {tabel }}$ yang diperoleh adalah 1,661.

Berdasarkan hasil uji t pada Tabel 4.4, maka hasil analisis pengaruh variabel bebas terhadap variabel terikat, sebagai berikut :

1. Dari hasil uji t, pada variabel Kualitas Produk, terlihat bahwa nilai Signifikansi ( $p$ value) dari kualitas produk sebesar 0,018 atau $<0,1$ dan $t_{\text {hitung }}$ sebesar 2,403 $>\mathrm{t}$ tabel (1,661). Berdasarkan hasil tersebut hipotesis 0 ditolak. Maka dapat dinyatakan bahwa variabel Kualitas Produk berpengaruh secara parsial dan signifikan terhadap variabel Keputusan Pembelian.

2. Dari hasil uji t, pada variabel Harga terlihat bahwa nilai Signifikansi (p value) dari Harga adalah 0,734>0,1 dan $\mathrm{t}_{\text {hitung }}$ sebesar $0,341<\mathrm{t}_{\text {tabel }}(1,661)$. Berdasarkan hasil tersebut hipotesis 0 diterima. Maka dapat dinyatakan bahwa variabel Harga tidak berpengaruh secara parsial dan signifikan terhadap variabel Keputusan Pembelian.

3. Dari hasil uji t, pada variabel Citra Merek terlihat bahwa nilai Signifikansi ( $p$ value) dari variabel Citra Merek adalah 0,012< 0,1 dan nilai $\mathrm{t}_{\text {hitung }}$ sebesar 2,576 $>\mathrm{t}$ tabel (1,661). Berdasarkan hasil tersebut hipotesis 0 ditolak. Maka dapat dinyatakan bahwa variabel Citra Merek berpengaruh secara parsial dan signifikan terhadap variabel Keputusan Pembelian.

\subsection{Uji Signifikansi Simultan (Uji F)}

Uji $F$ digunakan untuk mengetahui apakah semua variabel bebas secara bersamasama atau simultan berpengaruh terhadap 
variabel terikat. Hasil uji $\mathrm{F}$ dapat dilihat pada tabel berikut.

\section{Tabel 10. Hasil Uji F}

\begin{tabular}{|c|c|c|c|c|c|c|}
\hline \multicolumn{7}{|c|}{ ANOVA $^{a}$} \\
\hline \multicolumn{2}{|c|}{ Model } & Sum of Squares & Df & Mean Square & $\mathrm{F}$ & Sig. \\
\hline 1 & Regression & 252.421 & 3 & 84.140 & 6.800 & $.000^{\mathrm{b}}$ \\
\hline & Residual & 1150.671 & 93 & 12.373 & & \\
\hline & Total & 1403.093 & 96 & & & \\
\hline
\end{tabular}

a. Dependent Variable: KEPUTUSAN PEMBELIAN

b. Predictors: (Constant), CITRA MEREK, KUALITAS PRODUK, HARGA

Sumber : Hasil Penelitian, 2018 (data diolah)

Penentuan $\mathrm{F}_{\text {tabel }}$ dari nilai df $1=\mathrm{k}-1=4$ $1=3$ dan $\mathrm{df} 2=\mathrm{n}-\mathrm{k}=97-4=93$ diperoleh nilai 2,70. Pada Tabel 4.5 di atas diperoleh nilai $F$ hitung sebesar 6,800 dengan $F_{\text {tabel }}$ sebesar 2,70, sehingga $F_{\text {hitung }}(6,800)>F_{\text {tabel }}(2,70)$, dan tingkat signifikansi $0,000<0,1$. Maka H0 ditolak, yang artinya variabel Kualitas Produk, Harga dan Citra Merek secara bersama-sama (simultan) berpengaruh signifikan terhadap Keputusan Pembelian air minum dalam kemasan merek Aqua di kelurahan Pabuaran Bogor.

\subsection{Uji Koefisien Determinasi $\left(R^{2}\right)$}

Dalam penelitian ini perhitungan koefisien determinasi untuk mengukur seberapa jauh kemampuan variabel-variabel bebas (Kualitas Produk, Harga, dan Citra Merek) dalam menjelaskan variabel terikat (Keputusan Pembelian). Hasil uji koefisien determinasi sebagai berikut.

Tabel 11. Hasil Uji Koefisien Determinasi

\begin{tabular}{|l|c|r|r|c|}
\hline \multicolumn{5}{|c|}{ Model Summary } \\
\hline Model & \multicolumn{1}{|c|}{$R$} & $R$ Square & $\begin{array}{c}\text { Adjusted R } \\
\text { Square }\end{array}$ & $\begin{array}{c}\text { Std. Error of the } \\
\text { Estimate }\end{array}$ \\
\hline 1 & $.424^{\mathrm{a}}$ & .180 & .153 & 3.518 \\
\hline
\end{tabular}

a. Predictors: (Constant), CITRA MEREK, KUALITAS PRODUK, HARGA

Berdasarkan Tabel 4.10 diperoleh nilai Adjusted $R$ Square sebesar 0,153, yang berarti kontribusi variabel Kualitas Produk, Harga dan Citra Merek terhadap variabel Keputusan Pembelian sebesar $15,3 \%$. Sementara sisanya sebesar $84,7 \%$ dipengarui faktor lainnya yang tidak dibahas dalam penelitian ini.

\section{KESIMPULAN DAN SARAN}

\subsection{Kesimpulan}

Berdasarkan pembahasan yang telah dilakukan, maka kesimpulan Penelitian sebagai berikut :

1. Pada penelitian ini memberikan hasil variabel Kualitas Produk dan Citra Merek secara parsial berpengaruh signifikan terhadap variabel Keputusan Pembelian air minum dalam kemasan merek Aqua di kelurahan Pabuaran Bogor. Hal ini bisa dilihat dari hasil uji $\mathrm{t}$ hitung variabel Kualitas Produk $(2,403)$ dan Citra Merek $(2,576)$ lebih besar dari $\mathrm{t}$ tabel $(1,661)$. Sedangkan variabel Harga secara parsial tidak berpengaruh signifikan terhadap variabel Keputusan Pembelian air minum dalam kemasan merek Aqua di kelurahan Pabuaran Bogor. PT. Aqua Danone perlu meningkatkan kualitas produk dan memperkuat Citra Merek Produk Aqua agar permintaan produk air minum merek Aqua semakin meningkat.

2. Variabel Kualitas Produk, Harga dan Citra Merek secara simultan berpengaruh signifikan terhadap variabel Keputusan Pembelian air minum dalam kemasan merek Aqua di kelurahan Pabuaran Bogor. Hal ini ditunjukkan nilai $F$ hitung $(6,80)$ lebih besat dari $F$ table $(2,70)$ dan nilai signifikansi sebesar 0,00 di bawah 0,1 .

3. Hasil uji koefisien determinasi menunjukkan besarnya pengaruh variabel Kualitas Produk, Harga dan Citra Merek terhadap Keputusan Pembelian air minum dalam kemasan merek Aqua di kelurahan Pabuaran Bogor sebesar 15,3\%. Sedangkan pengaruh variabel lain yang tidak diteliti pada penelitian ini sebesar $84,7 \%$. PT Aqua Danone perlu melakukan penelitian lanjut dengan menggunakan variabel-variabel lain, seperti variabel Promosi, yang 
kemungkinan memberikan pengaruh lebih besar terhadap keputusan pembelian konsumen.

\subsection{Saran}

Setelah melakukan penelitian, pembahasan dan merumuskan kesimpulan dari hasil penelitian, maka penulis memberikan saran yang berkaitan dengan penelitian ini. Adapun saran dari penulis yaitu sebagai berikut :

1. PT. Aqua Danone perlu meningkatkan kualitas produknya, seperti membuat variasi kemasan botol ukuran $220 \mathrm{ml}$, dan design kemasan baru sehingga selalu menarik minat konsumen dan mampu menjangkau konsumen di berbagai segmen.

2. PT. Aqua Danone perlu menciptakan beraneka ragam produk baru, seperti produk air mineral dengan berbagai varian rasa seperti buah-buahan, sehingga dapat menarik minat masyarakat membeli air minum merek Aqua, yang secara otomatis akan meningkatkan penjualan produk air minum merek Aqua.

3. Perusahan PT. Aqua Danone diharapkan meningkatkan kekuatan Citra Merek produk Aqua dengan memperbanyak aktifitas dukungan bagi aktivitas-aktifitas atau event-event masyarakat yang mampu memberikan citra positif dan baik terhadap air minum merek Aqua.

\section{DAFTAR PUSTAKA}

Juliandi, A. dan Irfan. 2013. Metodologi Penelitian Kuantitatif Untuk Ilmu-ilmu Bisnis. Citapustaka Media Perintis, Bandung.

Ghozali, I. 2005. Aplikasi Analisis Multivariat dengan SPSS. Badan Penerbit UNDIP, Semarang.

Kotler, P dan Armstrong, G. 2012. Principles of Marketing. Pearson Education Limited, New Jersey.
Kotler, P. 2009. Manajemen Pemasaran. Edisi Ketigabelas. Erlangga, Jakarta.

Kotler, P. dan Keller, K.L. 2013. Manajemen Pemasaran, Jilid Kedua. Erlangga, Jakarta.

Swastha, B. dan Handoko, T.H. 2008. Manajemen Pemasaran. Jilid Empat, Edisi Pertama. Penerbit BPFE, Yogyakarta.

Sugiyono. 2015. Metode Penelitian Kombinasi (Mix Methods). Alfabeta, Bandung.

Sujarweni, V.W. 2015. Statistik Untuk Bisnis dan Ekonomi. Pustaka Baru Press, Yogyakarta.

Tjiptono, F. 2008. Strategi Pemasaran.: Penerbit Andi, Yogyakarta. 